\section{Monsanto sues over BST}

Washington. Monsanto Company has sued two dairy producers for allegedly misleading the public by advertising their milk products as not coming from cows treated with recombinant bovine somatotropin (rBST).

The company, based in St Louis, Missouri, says it acted because the two companies failed to comply with the interim guidelines on voluntary labelling of rBSTfree milk and milk products, issued last month by the US Food and Drug Administration (FDA) (see Nature 367, 585; 1994), which warn against the use of statements such as "from cows not treated with rBST" unless the claim is put in a proper context.

While Monsanto is asking the FDA and state regulatory authorities to enforce the guidelines, at least one state - Vermont seems likely to respond to consumer concern by passing a law that will require special labelling for milk or milk products from rBST-treated cows.

Monsanto has filed suit against Swiss Valley Farms Company of Davenport, Iowa, and the Pure Milk and Ice Cream Company of Waco, Texas. In a written statement, Monsanto says that their rBST-free claims are potentially misleading and fail to tell consumers that there is no significant compositional difference between milk from treated or untreated cows. In short, "they falsely imply... that labelled products are safer, more wholesome, and in other ways superior" to milk from rBST-treated cows.

Monsanto is the only company with FDA approval to sell rBST, a bioengineered growth hormone that boosts cows' production of milk. The company sells it under the brand name Posilac. Opponents of rBST argue that consumers have the right to know if it has been used, and that dairies should therefore have the right to label their products as rBST-free.

Andrew Kimbrell of the Foundation on Economic Trends (FET), a Washington lobby group opposed to genetic engineering, says that by taking such a hard line with these two companies, Monsanto is hoping to snatch a quick victory to use as a precedent against the larger companies. It is "a classic bullying tactic", he says.

Even with interim labelling guidelines in place, some states may opt for mandatory labelling in the face of mounting consumer pressure. The state legislature in Vermont last week voted in favour of a bill that would require dairy farmers who use rBST to notify dairy processors and cooperatives of the fact, and would require mandatory labelling of all milk and milk products from rBSTtreated cows sold within the state.

The FET has filed a legal petition with the FDA citing a possible conflict of interest with the agency's deputy commissioner for policy, Michael Taylor. From 1984 to 1991, labelling, which Taylor approved.

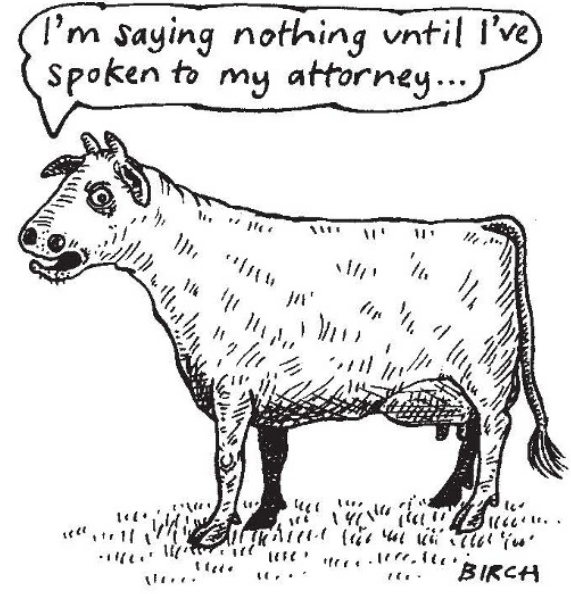

Taylor was a partner in the law firm of King \& Spalding in Washington, DC, with clients that included Monsanto. The petition calls for an investigation of Taylor's work at the FDA by the inspector-general of the Department of Health and Human Services and by Congress, and requests that the agency rescind its interim guidelines on voluntary

FDA commissioner David Kessler sprang to Taylor's defence, saying that he broke no laws or regulations and has adhered to the right ethical standards at all times. Kessler says that for his first year at the FDA, Taylor agreed not to participate in any specific matters relating to Monsanto, and was not involved in the agency's decision to approve Posilac last November. Diane Gershon

\title{
Commercial family planning for India
}

New Delhi. Frustrated by the delays faced by government scientists in getting research results turned into marketable products, a group of reproductive biologists at the Indian Institute of Science (IIS) in Bangalore have set up a company to manufacture and distribute birth control products.

The new company, called Reproductive Biotechnologies Private Limited (RBPL), seeks to make the entire range of family planning and reproductive services - now monopolized by the government - available through the private sector.

The scientists responsible for setting up the company include P. R. Adiga, M. R. Moudgal and G. Padmamabhan, all full professors at IIS, and T. C. Anandkumar, a former IIS research scientist and past director of the Institute for Research in Reproduction in Bombay.

The creation of the RBPL, says Anandkumar, is in line with both the current liberalization policies of the government, and pressures on research institutions to raise money through links with the private sector.

Although scientists at IIS will act as

\section{High hopes for new Australian minister}

Sydney. Australian scientists are hoping that the status of science policy in top-level government discussions will have been raised as a result of a ministerial reshuffle last week by Paul Keating, the prime minister.

The reshuffle was caused by the departure of several key ministers and means that Chris Schacht, previously minister for science and small business, will lose the science part of his portfolio to Peter Cook, the minister of industry. Cook is a senior and influential politician who (unlike Schacht) is a member of the 17-strong inner cabinet which makes all major government decisions.

Nothing has been publicly said about the reasons for the change in minister. But Schacht's two major proposals for reorganizing government science had created considerable ill-will among the scientists who would have been affected, and were blocked last year.

One of these was to create a Marine Institute out of various parts of the Commonwealth Scientific and Industrial Research Organization (see Nature 366, 97; 1993). This proposal is to be referred to a committee; but having lost a major supporter, its future is now in doubt

As the head of an 'outer' ministry, Schacht had only limited access both to the cabinet and to Keating. He remains minister for small business and customs, and has been given additional responsibility for construction.

Mark Lawson

advisers to the company and take part in collaborative research projects, they will not be allowed to take up salaried posts with the company while they are still in the service of IIS.

According to Anandkumar, the company is also being supported by scientists working elsewhere in India on research into reproduction. Money for the venture will be raised through the sale of equity shares and commercial loans.

Anandkumar says that one reason for setting up the company was the difficulty faced by government-supported scientists in transferring their discoveries quickly to the marketplace. Both Adiga and Moudgal, for example, had developed a birth control vaccine more than a decade ago, and both will retire from IIS before their products reach the market.

RBPL intends to identify promising reproductive technologies that need a capital investment to be developed into marketable products. One such product which will be manufactured soon is a hormonal nasal spray, an alternative to the oral pill.

K. S. Jayaraman 